\title{
PERSEPSI MASYARAKAT TERHADAP KEBERADAAN HUTAN TANAMAN INDUSTRI (HTI) PT. FINNANTARA INTIGA DI DESA TERATI KECAMATAN JANGKANG KABUPATEN SANGGAU
}

\author{
(Local Perception Of The Forest Of Industrial Plants (HTI) Of PT. Finnantara Intiga In The \\ Village Of Terati Jangkang Subdistrict Regency Of Sanggau)
}

\author{
Deli, H. A. Oramahi, M. Idham \\ Fakultas Kehutanan Universitas Tanjungpura Jl. Daya Nasional, Pontianak 78124 \\ E-mail : Dellymus1311@gmail.com
}

\begin{abstract}
Terati Village is one of the villages in Jangkang District which has quite extensive forest resources. With the existence of HTI PT. Finnantara Intiga in Terati Village, it certainly can affect the socio-economic life of the communit. Industrial timber plantations (HTI) are production forest areas that apply intensive forestry cultivation (silviculture) to meet the raw material of the forestry industry, both timber and non timber. In the midst of the scarcity of natural production forests, HTI is the foundation of future forest product production. Exploitation of natural forest products since the 70s has become a significant source of state income. The method used is a survey method with interview techniques. Sampling was done intentionally (purposive sampling). The number of samples taken was 83 respondents who live in Terati Village. Characteristics of respondents taken are a minimum age of 19-65 years, Have lived at least 5 (five) years in the Village of Terati, Can read and write Healthy physically and spiritually. Data analysis consists of community perceptions, the relationship between age, knowledge, cosmopolitan and income and community perceptions.based on the results of data and calculations of the four variables for the age category with community income there is no relationship with community perception, while for the category of knowledge and cosmopolitan there is a real relationship with community perception. The observation shows that 17 respondents (20.48\%) tend to have a high perception of the existence of HTI PT. Finnantara Intiga in Terati Village, Jangkang Subdistrict, Sanggau Regency, 52 respondents (62.65\%) tended to have a moderate perception of the existence of PT. Finnantara Intiga in Terati Village, Jangkang District, Sanggau Regency and 14 (16.47\%) respondents tended to have a low perception of the existence of PT. Finnantara Intiga in Terati Village, Jangkang District, Sanggau Regency.
\end{abstract}

keywords: community perception, cosmopolitan, income with community perception, influencing factors and knowledge.

\section{PENDAHULUAN}

Hutan memiliki peranan yang sangat penting dalam suatu lingkungan masyarakat mau pun global.Pembangunan HTI hingga saat ini memberikan pengaruh terhadap kondisi kehidupan masyarakat yang berada disekitar kawasan HTI, karena secara langsung masyarakat tersebut memiliki keterkaitan dengan kawasan hutan.Masih banyak kontroversi di seputar ekspansi hutan tanaman: ekspansi tersebut dipuji oleh sebagian orang karena kemampuannya untuk memproduksi kayu dalam jumlah besar secara efisien, mengurangi tekanan atas hutan alam, menciptakan lapangan kerja yang menyokong pembangunan desa, 
atau menyediakan sejumlah jasa lingkungan khususnya ketika hutan tanaman tersebut dibuat di lahan terdegradasi yang memerlukan upaya restorasi (Bauhus etal. 2010; Barat et al. 2013, 2014).Desa Terati merupakan salah satu desa di Kecamatan jangkang yang memiliki sumber daya hutan yang cukup luas. Dengan adanya HTI PT.Finnantara Intiga di Desa Terati tentu dapat mempengaruhi kehidupan sosial ekonomi masyarakat.Tujuan dari penelitian adalah untuk menentukan kriteria persepsi masyarakat (tinggi, sedang, rendah), dan Menganalisis hubungan dari masing-masing faktor: umur, pengetahuan, kosmopolitan dan pendapatan dengan persepsi masyarakat di Desa Terati Kecamatan Jangkang Kabupaten Sanggau

\section{METODE PENELITIAN}

Penelitian ini dilaksanakan di Desa Terati Kecamatan Jangkang Kabupaten Sanggau, dengan waktu penelitian dilapangan selama 3 minggu. Penelitian ini menggunakan metode survei yang bersifat deskriptif kuantitatif, teknik pengambilan data dengan cara wawancara dan alat bantu kuisioner. Untuk menentukan responden dilakukan dengan cara purposive sampling (disengaja), kemudian untuk menentukan besaran sampel penelitian menggunakan rumus slovin (Husein Umar, 2004).

$$
\mathrm{n}=\frac{\mathrm{N}}{1+\mathrm{Ne}^{2}}
$$

Keterangan:

n : Jumlah sampel

$\mathrm{N}$ : Jumlah populasi

$e^{2}:$ batas toleransi kesalahan

(dalam penelitian ini adalah 10\%)

Dengan menetapkan rumus diatas, maka jumlah sampel yang diperoleh dengan taraf signikansi $10 \%$ yaitu :

Kemudian agar lebih proporsional maka harus dicari besarnya sampel yang diambil dari masing-masing dusun dengan menggunakan rumus alokasi proporsional sebagai berikut:

$$
\mathrm{n}=\frac{\mathrm{Ni} \times \mathrm{ni}}{\mathrm{N}}
$$

Keterangan :

Ni: Jumlah proporsi sampel dari masing-masing kelompok

ni : Jumlah populasi dari masingmasing kelompok

$\mathrm{n}: \quad$ Jumlah sampel yang diambil

$\mathrm{N}$ : Jumlah total populasi

Berdasarkan populasi dan sampel tiap dusun di Desa Terati kecamatan Jangkang Kabupaten Sanggau. 
Tabel 1.Jumlah populasi dan sampel masing-masing dusun di Desa Terati Kecamatan Jangkang Kabupaten Sanggau.(The population and sample of each hamlet in Terati Village, Jangkang District, Sanggau Regency)

\begin{tabular}{lcc}
\hline \multicolumn{1}{c}{ Dusun } & Jumlah KK & Sampel \\
\hline Terati & 68 & 11 \\
Sipan Jaya & 52 & 9 \\
Parai & 133 & 22 \\
Rubia & 71 & 12 \\
Sei Puteh & 72 & 12 \\
Dasan & 49 & 8 \\
Sei Bayang & 51 & 9 \\
\hline Jumlah & 494 & 83 \\
\hline
\end{tabular}

Pengumpulan data dilakukan dengan datang langsung kelokasi penelitian, dengan dibantu dengan kuesioner, populasi dalam penelitian ini adalah masyarakat yang tinggal disekitar lokasi penelitian yaitu HTI PT. Finnantara Intiga didesa terati kecamatan jangkang kabupaten sanggau 494 KK atau 2024 jiwa, dari jumlah Kepala Keluarga tersebut sebanyak 20 KK digunakan sebagai uji validitas. Dan jumlah Kepala Keluarga yang di ambil sebagai sampel penelitian yaitu 474 .

Teknik analisis data yaitu dengan mengumpulkan data dari responden penelitian berupa data kualitatif dan di transformasi kedalam bentuk kuantitatif. Data mengenai persepsi, umur, pengetahuan, kosmopolitan dan pendapatan akan ditabulasikan sebagaimana mestinya dengan cara memberikan skor pada setiap jawaban pertanyaan (kuesioner).

Variabel terikat dalam penelitian ini adalah persepsi masyarakat Desa Terati terhadap keberadaan Hutan Tanaman Industri PT. Finnantara Intiga. Untuk mengukur variabel tingkat persepsi masyarakat sekitar terhadap Hutan Tanaman Industri dengan memberikan skor pada setiap jawaban responden dari kuesioner. Untukpertanyaan yang mengukur nilai positif diberi skor $\mathrm{a}=5, \mathrm{~b}=$ $4, \mathrm{c}=3, \mathrm{~d}=2$, dan $\mathrm{e}=1$. Sedangkan untuk pertanyaan yang mengukur nilai negatif diberi skor $\mathrm{a}=1, \mathrm{~b}=2, \mathrm{c}=3, \mathrm{~d}=4$ dan $\mathrm{e}$ $=5$.

Kemudian skor-skor yang diperoleh dari setiap responden dijumlahkan secara keseluruhan dan diambil nilai rata-rata. Nilai rata-rata tersebut kemudian ditentukan dengan ketentuan bahwa responden yang termasuk kategori tinggi dengan skor > 3,5, sedang dengan skor 2,5-3,5 dan rendah jika skor $<2,5$.

Sedangkan variabel bebasnya seperti, umur, penegetahuan, kosmopolitan dan umur masyarakat.

a. Untuk menentukan kelompok umur Menurut Nurmalasari (2007), golongan yang lazim pada umur untuk penelitian ini yaitu memiliki kematangan fisik maupun emosional yang tinggi pada masyarakat ialah mereka yang termasuk tingkat usia 
20-64 tahun, dan dikelompokkan sebagai berikut.

(1). usia muda berkisar dari umur 20-34 tahun,

(2). untuk umur dewasa 35-49 tahun, dan

(3). untuk usia lanjut berkisar antara 50-64 tahun.

b. Untuk menentukan kelompok tingkat pengetahuan masyarakat.

(1). Tinggi, jika rata-rata dari skor pertanyaan mengenai persepsi dan pengetahuan masyarakat > 3,5.

(2). Sedang, jika rata-rata dari skor pertanyaan mengenai persepsi dan pengetahuan masyarakat antara 2,5-3,5

(3). Rendah, jika rata-rata dari skor pertanyaan mengenai persepsi dan pengetahuan masyarakat < 2,5.

c. Untuk menentukan kelompok tingkat kosmopolitan masyarakat.

(1). Tinggi, jika rata-rata dari skor pertanyaan mengenai persepsi dan pengetahuan masyarakat > 3,5 .

(2). Sedang, jika rata-rata dari skor pertanyaan mengenai persepsi dan pengetahuan masyarakat antara 2,5-3,5

(3). Rendah, jika rata-rata dari skor pertanyaan mengenai persepsi dan pengetahuan masyarakat < 2,5.

d. Untuk menentukan kelompok pendapatan masyarakat (variabel bebas) digunakan rumus standar deviasi (Darmadi,2011) dengan rumus sebagai berikut:
$\bar{x}=\frac{\Sigma x \mathrm{i}}{n}$

Dimana :

$x i=$ Rata-rata penghasilan

$n=$ Jumlah Responden

$\mathrm{SD}=\frac{\sqrt{n \sum x \mathrm{i}^{2}-\left(\sum x \mathrm{i}^{2}\right)}}{n(n-1)}$

Dimana :

$S D=$ Standar Deviasi

$n=$ Jumlah Responden

$x i=$ Pendapatan ke $i$

Tingkat pendapatan tersebut dapat dikategorikan sebagai berikut :

(1). Tinggi, jika pendapatan masyarakat $>\bar{x}+\mathrm{SD}$.

(2). Sedang, jika pendapatan masyarakat antara $\bar{x}+\mathrm{SD}-\bar{x}-\mathrm{SD}$.

(3). Rendah, jika pendapatan masyarakat $<\bar{x}-\mathrm{SD}$.

Uji Validitas menggunakan rumus yang dikemukakan oleh Pearson (Arikunto, 1993). Rumus korelasi product moment yaitu sebagai berikut : $r_{x y}=\frac{\left.\mathrm{N} \sum \mathrm{xy}\right)-\left(\sum \mathrm{x}\right) \cdot\left(\sum \mathrm{y}\right)}{\sqrt{\left\{\mathrm{N} \sum \mathrm{x}^{2}-(\mathrm{x})^{2}\right\}\left\{\mathrm{N} \sum \mathrm{y}^{2}-\mathrm{y}^{2}\right\}}}$

$\mathrm{N}=$ Jumlah Responden

$\mathrm{X}=$ Skor Pertanyaan Bilangan Genap

$\mathrm{Y}=$ Skor Pertanyaan Bilangan Ganjil

rxy $=$ Koefesien Korelasi

Uji Reliabilitas yang digunakan adalah rumus Sperman-Brown (Arikunto, 1989), yaitu sebagai berikut : $r 11=\frac{2 \cdot r \cdot 1 / 2 \cdot r \cdot 1 / 2}{(1+r \cdot 1 / 2 \cdot 1 / 2)}$

Dimana:

$\mathrm{r} 1 / 2.1 / 2=$ Korelasi product moment antara skor-skor antara belahan tes

$r 11=$ Koefesien Reliabilitas 
Pengujian hipotesis dalam penelitian ini yakni tingkat persepsi masyarakat terhadap keberadaan Hutan Tanaman Industri (hipotesis diskriptif), dan hubungan antara tingkat pengetahuan, umur dan pendapatan dengan persepsi masyarakat lokal terhadap keberadaan Hutan Tanaman Industri Didesa Terati Kecamatan Jangkang Kabupaten Sanggau digunakan analisis distribusi frekuensi dan distribusi tabulasi silang yang kemudian di uji dengan teknik uji statistik non-parametrik Chi-Kuadrat. Untuk mengetahui tingkat persepsi masyarakat, maka data yang diperoleh terlebih dahulu dimasukan kedalam tabel frekuensi. Dari tabel frekuensi tersebut kemudian dianalisis dengan menggunakan Chi-kuadrat Singarimbun (1989) sebagai berikikut:

Rumus lengkap Chi-Kuadrat adalah :

$$
x^{2}=\sum_{i=1}^{k}\left(\frac{f o-f e}{f e}\right)^{2}
$$

Dimana :

$x^{2}=$ Chi-Kuadrat

fo $\quad=$ Frekuensi yang diobservasi

fe $\quad=$ Frekuensi yang diharapkan

Untuk menghitung frekuensi yang diharapkan (ft) pada hipotesis deskriptif rumusnya adalah sebagai berikut :

$$
f_{e}=\frac{\Sigma n}{\Sigma \mathrm{k}}
$$

Dimana :

$f e=$ Frekuensi yang diharapkan

$\Sigma n=$ Banyaknya Sampel

$\Sigma \mathrm{k}=$ Banyaknya Kategori.
Selanjutnya dari tabulasi silang dilakukan uji statistik dengan rumus Chi Kuadrat (Singarimbun,1989), yaitu :

$$
x^{2}=\sum_{i=1}^{k} \frac{(f o-f e)^{2}}{f_{e}}
$$

Dimana :

$x^{2}=$ Chi Kuadrat

$f_{0}=$ Frekuensi yang diperoleh

$f_{e}=$ Frekuensi yang diharapkan

Frekuensi yang diharapkan $\left(f_{e}\right)$ dapat dihitung dengan rumus :

$$
f_{e}=\frac{\text { Ekolom } x \text { Ebarisn }}{\mathrm{n}}
$$

Hubungan antara variabel terikat dengan variabel bebas dapat menggunakan dihitung menggunakan kriteria uji sebagai berikut :

(1). Jika $x^{2}$ hitung $\geq x^{2}$ tabel : berarti terdapat hubungan yang signifikan antara persepsi dan faktor-faktor yang mempengaruhi persepsi masyarakat.

(2). Jika $x^{2}$ hitung $<x^{2}$ tabel : berarti tidak terdapat hubungan yang signifikan antara persepsi dan faktor-faktor yang mempengaruhi persepsi masyarakat. Taraf Signifikan yang digunakan yaitu $5 \%$.

Untuk mengetahui keeratan hubungan antara faktor tingkat umur, pengetahuan, cosmopolitan dan pendapatandengan persepsi masyarakat lokal terhadap HTI PT. Finnantara Intiga di Desa Terati Kecamatan Jangkang Kabupaten Sanggau dapat menggunakan rumus koefisien kontingensi (Sugiyono,2014) yaitu : 


$$
C=\sqrt{\frac{x^{2}}{x^{2}+n}}
$$

Dimana :

$\mathrm{C}=$ Koefisien kontingensi

$x^{2}=$ Chi-Kuadrat

$n=$ Jumlah responden

Agar nilai $\mathrm{C}$ yang diperoleh dapat digunakan untuk menilai derajat asosiatif antara variabel terikat maka nilai $\mathrm{C}$ ini perlu dibandingkan dengan koefisien kontingensi makasimum. Nilai $\mathrm{C}$ tersebut berkisar antara 0,00-1,000 jika nilai $\mathrm{C}$ semakin besar maka hubungan antara dua variabel semakin erat. Pedoman untuk memberikan interpretasi koefisien kontingensi digunakan batasan yang di ungkapkan Sugiyono (2014) yang di sajikan pada tabel berikut ini :

Tabel 2. Nilai Interpretasi Koefisien Korelasi dan Tingkat Hubungan (The value of the correlation Coefficient and degree of Interpretation of relations)

\begin{tabular}{lc}
\hline Interval Koefisien & Tingkat Hubungan \\
\hline $0,00-0,199$ & Sangat Rendah \\
$0,20-0,399$ & Rendah \\
$0,40-0,599$ & Sedang \\
$0,60-0,799$ & Kuat \\
$0,80-1,000$ & Sangat Kuat \\
\hline
\end{tabular}

Sumber : Sugiyono 2014

\section{HASIL DAN PEMBAHASAN}

Masyarakat Desa Terati yang memiliki persepsi tinggi adalah 20,48 $\%$, masyarakat yang memiliki persepsi sedang $62,65 \%$ dan masyarakat yang memiliki persepsi rendah $16,87 \%$. Sepeti terlihat pada tabel 3.

Tabel 3. Persepsi Masyarakat Lokal Terhadap Keberadaan HTI PT. Finnantara Intiga di Desa Terati Kecamatan Jangkang Kabupaten Sanggau. (Perception of Local Communities Against the Existence of HTI PT. Finnantara Intiga in Terati Village, Jangkang District, Sanggau Regency).

\begin{tabular}{llcc}
\hline No & Persepi & Frekuensi & $(\boldsymbol{\%})$ \\
\hline 1 & Tinggi & 17 & 20,48 \\
2 & Sedang & 52 & 62,65 \\
3 & Rendah & 14 & 16,87 \\
\hline & Jumlah & $\mathbf{8 3}$ & $\mathbf{1 0 0 , 0 0}$ \\
\hline
\end{tabular}

Hasil uji chi kuadrat didapatkan hasil bahwa nilai $x^{2}$ hitung $=32,25$ sedangkan $\mathrm{x}^{2}$ Tabel $=5,991$. Dari hasil diatas menunjukkan bahwa $\mathrm{H}_{0}$ ditolak $\mathrm{H}_{1}$ diterima. Dari tabel 1 diatas dapat dilihat bahwa masyarakat yang persepsinya sedang jauh lebih banyak dibandingkan persepsi masyarakat yang tinggi dengan yang rendah, yaitu 52 responden $(62,65 \%)$ dengan persepsi sedang. Sedangkan untuk persepsi masyarakat yang tinggi dengan yang 
rendah tidak jauh berbeda yaitu 17 $(20,48 \%)$ persepsi tinggi dan 14 $(16,47 \%)$ yang persepsinya rendah. Penelitin terdahulu berdasarkan hasil kesimpulan Siti Lestari (2016) tingkat umur dan tingkat pendapatan berpengaruh tidak nyata terhadap persepsi masyarakat.

Berdasarkan hasil penelitian menunjukkan bahwa sebagian masyarakat memiliki persepsi sedang, masyarakat yang memiliki persepsi Sedang yaitu masyarakat yang raguragu untuk menentukan persepsi mereka terhadap Keberadaan HTI PT. Finnantara Intiga Di Desa Terati. dari hasil data Tabel 1 terdapat $52(62,65 \%)$ responden hal tersebut menunjukkan bahwa sebagian besar mayarakat berpendapat keberadaan HTI PT. Finnantara Intiga Di Desa Terati tidak memiliki pengaruh yang besar terhadap keadaan sosial ekonomi masyrakat. Berdasarkan hasil wawancara dengan masyarakat, masyarakat menilai bahwa kinerja suatau perusahaan masih belum maksimal mereka menilai pembangunan terhadap jalan yang ada pada saat ini masih lemah, disisi lain masyarakat juga menilai bahwa dari segi ekonomi juga tidak mampu merubah keadaan ekonomi untuk mensejahterakan masyarakat. Namun disisi lain masyarakat menyadari bahwa dengan adanya HTI PT. Finnantara Intiga Di Desa Terati akses jalan untuk keluar masuk kesuatu daerahh sudah jauh berubah dibandingkan waktu sebelumnya walaupun akses jalan yang ada belum maksimal, oleh sebab itu masyarakat cenderung memiliki persepsi sedang terhadap Keberadaan HTI PT. Finnantara Intiga di Desa Terati Kecamatan Jangkang Kabupaten Sanggau.

Masyarakat yang memiliki persepsi tinggi terdapat $17(20,48 \%)$ responden, hal ini menunjukkan bahwa sebagian masyarakat berpendapat bahwa Keberadaan HTI PT. Finnantara Intiga Di Desa Terati Kecamatan Jangkang Kabupaten Sanggau, dapat menunjang kehidupan masyarakat baik dari segi ekonomi maupun sosial.

Masyarakat yang memiliki persepsi rendah terdapat $14(16,87 \%)$ responden kemudian masyarakat yang memiliki persepsi rendah menilai bahwa Keberadaan HTI PT. Finnantara Intiga di Desa Terati masih jauh dari harapan masyarakat atau tidak memiliki kontribusi yang cukup untuk mampu merubah keadaan ekonomi maupun sosial dalam lingkungan masyarakat setempat.

Hubungan Umur Dengan Persepsi Masyarakat Lokal Terhadap Keberadaan HTI PT. Finnantara Intiga Di Desa Terati Kecamatan Jangkang Kabupaten Sanggau

Hubungan antara Umur Dengan Persepsi Masyarakat Lokal Terhadap Keberadaan HTI PT. Finnantara Intiga Di Desa Terati Kecamatan Jangkang Kabupaten Sanggau dapat dilihat pada Tabel. 
Tabel 4. Hubungan Umur Dengan Persepsi Masyarakat Lokal Terhadap Keberadaan HTI PT. Finnantara Intiga Di Desa Terati Kecamatan Jangkang Kabupaten Sanggau (Relationship between Age and Local Community's Perception on the Existence of HTI of PT. Finnantara Intiga in Terati Village, Jangkang District, Sanggau Regency).

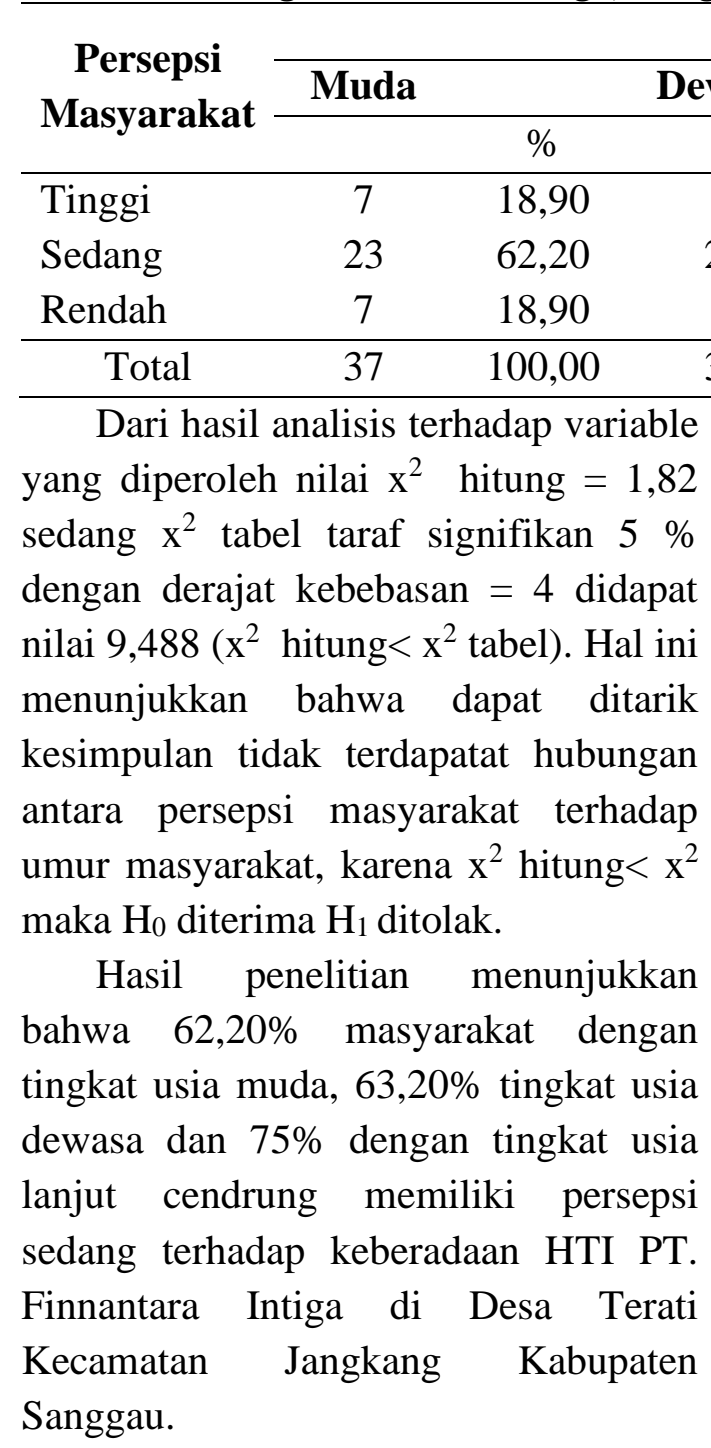

Kategori Umur

\begin{tabular}{|c|c|c|c|c|c|c|c|}
\hline \multirow{3}{*}{$\begin{array}{c}\text { Persepsi } \\
\text { Masyarakat }\end{array}$} & \multirow{3}{*}{ Muda } & & \multirow{3}{*}{$\Sigma$} \\
\hline & & \multirow[b]{2}{*}{$\%$} & \multirow{2}{*}{ Dewasa } & \multicolumn{3}{|c|}{ Tua } & \\
\hline & & & & $\%$ & & $\%$ & \\
\hline Tinggi & 7 & 18,90 & 7 & 18,40 & 2 & 25,00 & 16 \\
\hline Sedang & 23 & 62,20 & 24 & 63,20 & 6 & 75,00 & 53 \\
\hline Rendah & 7 & 18,90 & 7 & 18,40 & 0 & 00,00 & 14 \\
\hline Total & 37 & 100,00 & 38 & 100,00 & 8 & 100,00 & 83 \\
\hline
\end{tabular}

yang diperoleh nilai $\mathrm{x}^{2}$ hitung $=1,82$ Hasil ini sejalan dengan penelitian terdahulu Rikardo (2016) mengungkapkan tidak terdapat hubungan antara umur dengan persepsi masyarakat, kemudian menurut Lestari (2016) yang menjelaskan tingkat umur berpengaruh tidak nyata dengan persepsi masyarakat.

Hubungan Pengetahuan Dengan Persepsi Masyarakat Lokal Terhadap Keberadaan HTI PT. Finnantara Intiga Di Desa Terati Kecamatan Jangkang Kabupaten Sanggau

Hubungan antara tingkat pengetahuan masyarakat dengan persepsi masyarakat lokal terhadap keberadaan HTI PT. Finnantara intiga di Desa Terati Kecamatan Jangkang Kabupaten Sanggau dilampirkan pada Tabel 5. 
Table 5. Hubungan pengetahuan dengan persepsi masyarakat lokal terhadap keberadaan HTI PT. Finnantara intiga di Desa terati kecamatan jangkang kabupaten sanggau (Relationship of knowledge with local community perceptions of the existence of HTI PT. Finnantara Intiga in Terati Village, Jangkang Subdistrict, Sanggau Regency)

\begin{tabular}{|c|c|c|c|c|c|c|c|}
\hline \multirow{3}{*}{$\begin{array}{c}\text { Persepsi } \\
\text { Masyarakat }\end{array}$} & \multicolumn{7}{|c|}{ Kategori pengetahuan } \\
\hline & Tingg & & Sedang & & Rend & & \multirow{2}{*}{$\mathbb{E}$} \\
\hline & \multicolumn{2}{|c|}{$\%$} & \multicolumn{2}{|c|}{$\%$} & \multicolumn{2}{|c|}{$\%$} & \\
\hline Tinggi & 16 & 37,20 & 1 & 3,33 & 1 & 10,00 & 18 \\
\hline Sedang & 22 & 51,20 & 22 & 73,33 & 5 & 50,00 & 49 \\
\hline Rendah & 5 & 11,60 & 7 & 23,33 & 4 & 40,00 & 16 \\
\hline Total & 43 & 100,00 & 30 & 100,00 & 10 & 100,00 & 83 \\
\hline
\end{tabular}

Hasil analisis terhadap variabel yang diperoleh nilai $\mathrm{x}^{2}$ hitung $=15,47$ sedangkan $\mathrm{x}^{2}$ tabel taraf signifikan $5 \%$ dengan derajat kebebasa $=4$ didapat nilai 9,488 ( $\mathrm{x}^{2}$ hitung $>\mathrm{x}^{2}$ tabel). Dari hasil ini dapat ditarik kesimpulan bahwa terdapat hubungan antar persepsi masyarakat terhadap tingkat pengetahuan masyarakat, karena $\mathrm{x}^{2}$ hitung $>\mathrm{x}^{2}$ tabel maka $\mathrm{H}_{0}$ ditolak $\mathrm{H}_{1}$ diterima.

Berdasarkan hasil penelitian menunjukkan bahwa $51,20 \%$ responden dengan tingkat pengetahuan tinggi 73,33\% dengan tingkat pengetahuan sedang dan
50,00\% responden dengan tingkat pengetahuan rendah cendrung memiliki persepsi sedang.

Hubungan Kosmopolitan Dengan Persepsi Masyarakat Lokal Terhadap Keberadaan HTI PT. Finnantara Intiga Di Desa Terati Kecamatan Jangkang Kabupaten Sanggau

Hubungan antara tingkat kosmopolitan masyarakat dengan persepsi masyarakat lokal terhadap keberadaan HTI PT. Finnantara Intiga Di Desa Terati Kecamatan Jangkang Kabupaten Sanggau dilampirkan pada Tabel 6.

Tabel 6. Hubungan Kosmopolitan Dengan Persepsi Masyarakat Lokal Terhadap Keberadaan HTI PT. Finnantara Intiga Di Desa Terati Kecamatan Jangkang Kabupaten Sanggau(Cosmopolitan Relationship with the Perception of Local Communities Against the Existence of HTI of PT. Finnantara Intiga in Terati Village, Jangkang District, Sanggau Regency).

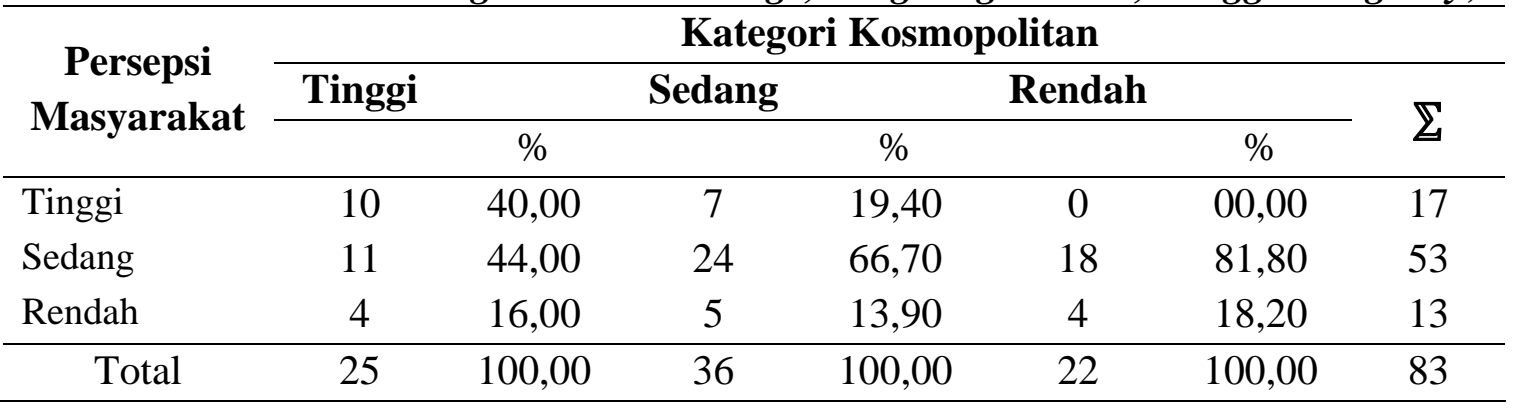


Hasil analisis terhadap variable yang diperoleh nilai $\mathrm{x}^{2} \quad$ hitung $=12,04$ sedangkan $\mathrm{x}^{2}$ tabel taraf signifikan $5 \%$ dengan derajat kebebasan $=4$ didapat nilai $9,488 \quad\left(x^{2}\right.$ hitung $>x^{2}$ tabel). Hal ini menunjukkan bahwa dapat ditarik kesimpulan bahwa terdapat hubungan antara persepsi masyarakat terhadap tingkat kosmopolitan masyarakat, karena $\mathrm{x}^{2}$ hitung $>\mathrm{x}^{2}$ tabel maka $\mathrm{H}_{0}$ ditolak $\mathrm{H}_{1}$ diterima.

Hasil menunjukkan bahwa 44,00\% masyarakat dengan tingkat pengetahuan tinggi, 66,70\% masyarakat dengan tingkat pengetahuan sedang dan $81,80 \%$ masyarakat dengan tingkat pengetahuan rendah cendrung memiliki persepsi sedang keberadaan HTI PT. Finnantara Intiga di
Desa Terati Kecamatan Jangkang Kabupaten Sanggau.

Sedangkan menurut Khairiansyah (2018) mengungkapkan tidak terdapat hubungan yang nyata antara tingkat kosmopolitan masyarakat dengan perepsi masyarakat.

Hubungan Pendapatan Dengan Persepsi Masyarakat Lokal Terhadap Keberadaan HTI PT. Finnantara Intiga Di Desa Terati Kecamatan Jangkang Kabupaten Sanggau

Tingkat pendapatan masyarakat dengan persepsi masyarakat lokal terhadap keberadaan HTI PT. Finnantara Intiga Di Desa Terati Kecamatan Jangkang Kabupaten Sanggau dilampirkan pada Tabel 7.

Tabel 7. Hubungan Pendapatan Dengan Persepsi Masyarakat Lokal Terhadap Keberadaan HTI PT. Finnantara Intiga Di Desa Terati Kecamatan Jangkang Kabupaten Sanggau(Relationship of Revenue with Local Community Perception of the Existence of HTI of PT. Finnantara Intiga in Terati Village, Jangkang District, Sanggau Regency).

\begin{tabular}{|c|c|c|c|c|c|c|c|}
\hline \multirow{3}{*}{$\begin{array}{c}\text { Persepsi } \\
\text { Masyarakat }\end{array}$} & \multicolumn{7}{|c|}{ Kategori Pendapatan } \\
\hline & \multirow[t]{2}{*}{ Tinggi } & \multicolumn{2}{|r|}{ Sedang } & \multicolumn{3}{|c|}{ Rendah } & \multirow{2}{*}{$\Sigma$} \\
\hline & & $\%$ & & $\%$ & & $\%$ & \\
\hline Tinggi & 1 & 14,30 & 14 & 19,70 & 2 & 40,00 & 17 \\
\hline Sedang & 5 & 71,40 & 45 & 63,40 & 2 & 40,00 & 52 \\
\hline Rendah & 1 & 14,30 & 12 & 16,90 & 1 & 20,00 & 14 \\
\hline Total & 7 & 100,00 & 71 & 100,00 & 5 & 100,00 & 83 \\
\hline
\end{tabular}

Hasil analisis terhadap variable yang diperoleh nilai $\mathrm{x}^{2}$ hitung $=1,64$ sedangkan $\mathrm{x}^{2}$ tabel taraf signifikan $5 \%$ dengan derajat kebebasan $=4$ didapat nilai $9,488\left(\mathrm{x}^{2}\right.$ hitung $<x^{2}$ tabel). Hal ini menunjukkan bahwa tidak terdapat hubungan antara tingkat pendapatan masyarakat terhadap persepsi masyarakat karena $\mathrm{x}^{2}$ hitung $<\mathrm{x}^{2}$ tabel maka $\mathrm{H}_{0}$ diterima $\mathrm{H}_{1}$ ditolak.
Berdasarkan hasil penelitian menunjukkan bahwa $71,40 \%$ dengan tingkat pendapatan tinggi, 63,40\% responden dengan tingkat pendapatan sedang dan40,00 \% responden dengan tingkat pendapatan rendah cendrung memiliki perepsi sedang. Kemudian $40,00 \%$ responden dengan tingkat pendapatan rendah memiliki 
kecendrungan yang sama antara memiliki persepsi tinggi dengan persepsi sedang terhadap keberadaan HTI PT. Finnantara Intiga Di Desa Terati Kecamatan Jangkang Kabupaten Sanggau.

Hasil ini sejalan dengan Penelitian terdahulu Setiawan (2016) faktor pendapatan masyarakat tidak menunjukkan hubungan yang nyata/signifikan dengan persepsi masyarakat.

\section{Kesimpulan}

Berdasarkan hasil penelitian dapat ditarik kesimpulan bahwa :

1. Persepsi Masyarakat Lokal Terhadap Keberadaan HTI PT. Finnantara Intiga Di Desa Terati Kecamatan Jangkang Kabupaten Sanggau, cendrung memiliki persepsi sedang.

2. Tidak terdapat hubungan antara umur dan pendapatan dengan Persepsi Masyarakat Lokal Terhadap Keberadaan HTI PT. Finnantara Intiga Di Desa Terati Kecamatan Jangkang Kabupaten Sanggau.

3. terdapat adanya hubungan antara pengetahuan dan kosopolitan dengan persepsi masyarakat lokal terhadap keberadaan HTI PT. Finnantara Intiga Di Desa Terati Kecamatan Jangkang Kabupaten Sanggau.

\section{Saran}

Jika dilihat dari persepsi masyarakat yang cendrung sedang, maka diharapkan kepada pihak perusahaan atau pun lembaga terkait untuk lebih memaksimalkan kinerjanya, karena keberadaan perusahaan merupakan peranan yang sangat penting bagi masyarakat setempat.

\section{DAFTAR PUSTAKA}

Arikunto, 1993. Prosedur Penelitian Suatu Pendekatan Praktik, Jakarta. PT. Rineka Cipta Khairiansyah M, Zainal S, Nugroho J. (2018). Persepsi Masyarakat Terhadap Keberadan Hutan Mangrove Di Kelurahan Kual Kecamatan Singkawang Barat Kota Singkawang. Jurnal Hutan Lestari 6 (2) : $416-427$.

Lestari S, Umar S, Alam S, A. (2016). Persepsi Masyarakat Terhadap Aspek Sosial Ekonomi Ruang Terbuka Hijau Taman Gor Dikota Palui Provinsi Sulawesi Tengah. Warta Rimba 4 : 74-81.

Rikardo R, Dirhamsyah M, Yani A. (2016) Persepsi Masyarakat Desa Senakin Terhadap Keberadaan Riam Solang Sebagai Hutan Wisata Alam Kecamatan Sengah Temila Kabupaten Landak. Jurnal Hutan Lestari 4 (2):143-150

Setiawan W, Nurdjali B, Dewantara I. (2015) Persepsi Masyarakat Desa Teluk Bakung Terhadap Keberdaan HTI PT. Kalimantan Subur Permai Kecamatan Sungai Ambawang Kabupaten Kubu Raya. Jurnal Hutan Lestari 4 (2) : 143-150

Singarimbun M, Sofian Effendi. 1989. Metode Penelitian Survey. LP3ES, Jakarta.

Sugiyono, 2014.Metode Penelitian Kuantitatif Kualitatif dan $R \& D$. Bandung : Cv. Alfabeta.

Umar H. 2004. Metode Penelitian Untuk Skripsi Dan Tesis Bisnis. Cetakan Ke-6. Jakarta: PT. Raja Grafindo Persada. 